\title{
A Concise Synthesis of 8-Oxoberberine and Oxychelerythrine, Natural Isoquinoline Alkaloids through Biomimetic Synthetic Way
}

\author{
Thanh Nguyen Le and Won-Jea Cho* \\ College of Phamacy and Research Institute of Drug Development, Chomam National Lniversity, Guangin 500-757, Korea \\ E-mail: wichoriminackr \\ Recerved August 9, 2006
}

Key Words : Benzo[c]phenanthridine alkaloid. Protoberberine alkaloid. Oxychelenthrine. 8-Oxoberberine. Biomimetic pathway

Natural isoquinoline alkaloids such as berberine and chelerythrine exhibit a variety of biological activities. Berberine has been isolated from several medicinal herbs. such as Hydrastis canadensis, Cortex phellodendri and Rhizoma coptidis which are widely distributed in plants and used as the traditional oriental medicine. Recently it has been attracted by the unique biological activities such as antidiabetic, ${ }^{3}$ anticancer ${ }^{4,5}$ and antinicrobial activities, One of the most interesting properties of berberine is that it exhibits cholesterol-lowering effect. ${ }^{2}$ Oral administration of berberine in 32 hypercholesterolemic patients for 3 months reduced serum cholesterol by $29 \%$. triglycerides by $35 \%$ and LDL-cholesterol by $25 \%{ }^{9}$ Emerging of this compound as new cholesterol-lowering drug pronipted us to develop new efficient synthesis of berberine.

Chelerythrine. a benzo|c|phenanthridine alkaloid, also has been investigated for its biological efficacy such as anti- tumor, ${ }^{10}$ inlubition of protein kinase $C .{ }^{11}$ induction of apoptosis through the generation of reactive oxygen and the stimulation of GSH transport. '?

Due to the interesting biological activities. the synthesis of protoberberine and benzo $[c /$ phenantluridines has been studied. ${ }^{1,13.14}$ Recently. we have also reported a versatile synthetic pathways for these alkaloids using lithiated toluamidebezonitrile cycloaddition. ${ }^{\text {Is. }}$.

As depicted in Scheme 1, benzo[c]phenanthridine alkaloid, chelerythrine. was proposed to be biosynthesized from the corresponding protoberberine alkaloid. ${ }^{17}$ In this pathway. the 3-arylisoquinolinone is a key intemediate for the cyclization step toward the benzorclphenanthridine skeleton.

We have reported the synthesis and QSAR studies of 3arylisoquinoline derivatives with antitumor activity. ${ }^{17.2 i}$ The synthetic strategy involved in the coupling reaction of $N$ methyl-o-toluamide with benzonitrile derivatives. ${ }^{21}$<smiles>COc1ccc2c(c1OC)CN1CCc3cc4c(cc3C1=C2)OCO4</smiles>

Protoberberine

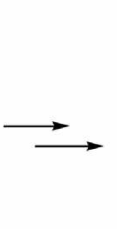<smiles>COc1ccc2c(c1OC)CN(C)C(c1cc3c(cc1CC=O)OCO3)=C2</smiles>

3-Arylisoquinoline<smiles>COc1ccc2c3cc4c(cc3ccc2[n+]1-c1ccccc1)OCO4</smiles>

Chelerythrine

Scheme 1. Biosynthetic pathway of benzo[c]phenanthridine alkaloid from protoberberine.<smiles>COc1ccc2cc3n(c(=O)c2c1OC)CCc1cc2c(cc1-3)OCO2</smiles>

8-oxoberberine (4)<smiles>CCc1cc2ooc2cc1-c1cc2ccc(OC)c(OC)c2c(=O)[nH]1</smiles>

3<smiles>COCCc1cc2c(cc1C#N)OCO2</smiles>

2

Scheme 2. Retrosynthesis of 8-oxoberberine 4 and oxychelery thrine 5. 
<smiles>COc1ccc(C)c(C(=O)NC(C)C)c1OC</smiles>

1

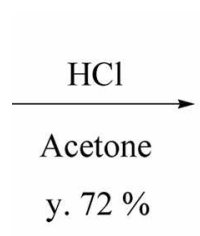

y. $72 \%$<smiles>COCCc1cc2c(cc1C#N)OCO2</smiles>

2<smiles>COCCc1cc2c(cc1-c1cc3ccc(OC)c(OC)c3c(=O)[nH]1)OCO2</smiles>

6<smiles>COc1ccc2cc3n(c(=O)c2c1OC)CCc1cc2c(cc1-3)OCO2</smiles>

8-oxoberberine (4)

Scheme 3. Synthesis of 8-oxoberberine 4 .<smiles>COCCc1cc2c(cc1-c1cc3ccc(OC)c(OC)c3c(=O)[nH]1)OCO2</smiles><smiles>COc1ccc2cc(-c3cc4c(cc3CCO)OCO4)n(C)c(=O)c2c1OC</smiles>

9

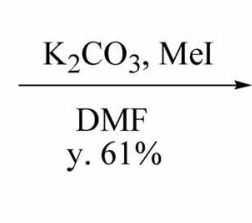

$\stackrel{\mathrm{PCC}, \mathrm{NaOAc}}{\longrightarrow}$
$\underset{\mathrm{CH}_{2} \mathrm{Cl}_{2}}{\text { y. } 65 \%}$<smiles>COCCc1cc2c(cc1-c1cc3ccc(OC)c(OC)c3c(=O)n1C)OCO2</smiles>

8<smiles>COC1=CC=c2c3c(c(n(C)c2=O)=c2cc4c(cc2=CC=3)OCO4)=C1</smiles>

oxychelerythrine (5)

Scheme 4 . Synthesis of oxycheleryturine 5 .

Retrosynthetic analysis of both alkaloids suggested that the coupling reaction of $o$-toluamide 1 with benzonitrile 2 affords 3-ary lisoquinoline 3 . which could be converted to 8 oxoberberine 4 via $\mathrm{S}_{\mathrm{S} 2}$ type cyclization of amide nitrogen. On the other hand. cyclization at $\mathrm{C} 4$ position could give oxychelerythrine 5 as shown in Scheme 2.

$N$-Methyllo-toluamide $1^{\text {t2 }}$ was lithiated with $n$-butyl lithium to give the dianion. which was treated with benzonitrile $2^{15}$ at $-50^{\circ} \mathrm{C}$ in THF to afford the 3 -arylisoquinoline- $1(2 H)$-one 6. Deprotection of MOM (methoxymethyl) with $10 \% \mathrm{HCl}$ gave the alcohol 7, which were then reacted with $p-\mathrm{TsCl}$ in DMF in the presence of triethylamine to afford the desired protoberberine alkaloid. oxyberberine 4 in $63 \%$ yield (Scheme 3).

The 3-arylisoquinoline intermediate 6 was treated with $\mathrm{MeI} / \mathrm{K}_{2} \mathrm{CO}_{3}$ provided the $N$-methylated product 8 without yielding $O$-methylated compounds in $61 \%$ yield. Hydrolysis of MOM group with $10 \% \mathrm{HCl}$ gave the alcohols 9 which was then oxidized with $\mathrm{PCC} / \mathrm{NaOAc}$ to provide the desired benzo[c]phenanthridine alkaloid. oxychelerythrine 5 in $65 \%$ yield (Scheme 4).

In conclusion. we accomplished a biomimetic synthesis of 8 -oxoberberine 4 and oxychelerythrine 5 in three and four steps. respectively. Efficiency and short sy'nthetic step made this process possible to be used as a general method for multi gram scale preparation of these alkaloids.

\section{Experimental Section}

Melting points were detemined by using the capillary method on Electrothennal IA9200 digital melting point apparatus and were uncorrected. Nuclear magnetic resonance (NMR) data for ${ }^{1} \mathrm{H}$ NMR was taken on Varian Unity 300 plus spectrometer and were reported in ppm, downfield from the peak of tetramethylsilane as an intenal standard. The data are reported as follows: chemical shift. number of proton. multiplicity (s: singlet. d: doublet. t: triplet. q: quartet. $\mathrm{n}$ : multiplet). IR spectra were recorded on JASCO-FT IR spectrometer using $\mathrm{CHCl}_{3}$ and $\mathrm{KBr}$ pellets. Mass spectra were obtained on JEOL JNS-DX 303 applying the electronimpact (EI) method. Column chromatography was performed on Merck silica gel 60 ( $70-230 \mathrm{mesh})$. TLC was carried out using plates coated with silica gel $60 \mathrm{~F} 254$ purchased from Merck. Chemical reagents were purchased from Aldrich Chemical Co. and used without further purification. Solvents were distilled prior to use: THF. ether were distilled from 


\section{sodium/ benzophenone}

7,8-Dimethoxy-3-[6-(2-methoxymethoxyethyl)benzo[1,3]dioxol-5-yl]-2H-isoquinolin-1-one (6). To the solution of amide $1(1.44 \mathrm{~g} .6 .8 \mathrm{mmol})$ in dry THF $(20 \mathrm{~mL})$ was added $n$-butyl lithium $(5.6 \mathrm{~mL}$ of $2.5 \mathrm{M}$ in hexane. $14 \mathrm{mmol}$ ) at $-20{ }^{\circ} \mathrm{C}$ and maintained the reaction temperature never exceeding $20^{\circ} \mathrm{C}$. After the red orange solution was stirred at $0^{\circ} \mathrm{C}$ for $1 \mathrm{~h}$ and cooled to $-50^{\circ} \mathrm{C}$, benzonitrile $2(1.35 \mathrm{~g} .5 .7$ mmol) was added dropwise. The reaction mixture was stirred at the same temperature for $20 \mathrm{~min}$ and allowed to warm up to room temperature. The reaction was quenched with water and extracted with ethyl acetate. The organic layer was washed with water. brine and dried over sodium sulfate. After removing the solvent in vactoo, the residue was purified by column chromatography with $n$-hexane-ethyl acetate (1:1) to afford 3-arylisoquinoline 6 as a sticky solid $(1.05 \mathrm{~g} .44 \%)$. IR $\left(\mathrm{cm}^{-1}\right): 3400(\mathrm{NH}) .1630(\mathrm{C}=\mathrm{O}) .{ }^{1} \mathrm{H}$ NMR $\left(300 \mathrm{MHz}, \mathrm{CDCl}_{3}\right) \delta .10 .30$ (s. IH). 7.34 (d. $J=8.7 \mathrm{~Hz} . \mathrm{lH}$ ). 7.25 (d. $J=8.7 \mathrm{~Hz}, 1 \mathrm{H}) .6 .85$ (s. 1H). 6.80 (s. $1 \mathrm{H}) .6 .32$ (s. $1 \mathrm{H}), 6.01(\mathrm{~s}, 2 \mathrm{H}), 4.74(\mathrm{~s}, 2 \mathrm{H}), 4.00(\mathrm{~s}, 3 \mathrm{H}), 3.95$ (s. 3H) $3.84(\mathrm{~m} .2 \mathrm{H}) .3 .25$ (s. 3H). 2.85 (m. 2H). MS. me (\%): 413 $\left(\mathrm{M}^{+} .10\right) .336$ (14). $222(59), 192(94), 174(100)$.

3-[6-(2-Hydroxyethyl)benzo[1,3]dioxol-5-yl]-7,8-dimethoxy- $2 H$-isoquinolin-1-one (7). To a solution of compound 6 (450 mg. $1.09 \mathrm{mmol}$ ) in THF (15 mL) was added $10 \% \mathrm{HCl}$ $(5 \mathrm{~mL}$ ) and then the reaction mixture was refluxed for $2 \mathrm{~h}$. It was poured into water and extracted with ethyl acetate. The ethyl acetate extract was washed with water. brine and dried over anhydrous sodium sulfate. After removing the solvent. the residue was purified by column chromatography on silica gel with $\mathrm{CH}_{2} \mathrm{Cl}_{2}: \mathrm{MeOH}(20: 1)$ to give an alcohol 7 as a yellow solid (290 $\mathrm{mg} .72 \%)$. $\mathrm{mp}: 218-220^{\circ} \mathrm{C}$. IR $\left(\mathrm{cm}^{-1}\right)$ : $3400(\mathrm{NH}, \mathrm{OH}), 1642(\mathrm{C}=\mathrm{O}) .{ }^{1} \mathrm{H}$ NMR $\left(300 \mathrm{MHz}, \mathrm{CDCl}_{3}\right)$ $\delta .11 .0$ (s. $1 \mathrm{H}) .7 .44$ (d, $J=8.7 \mathrm{~Hz}, \mathrm{IH}) .7 .3 \mathrm{l}(\mathrm{d}, J=8.7 \mathrm{~Hz}$. $1 \mathrm{H}) .6 .90(\mathrm{~s} .1 \mathrm{H}) .6 .82(\mathrm{~s} .1 \mathrm{H}) .6 .28(\mathrm{~s} .1 \mathrm{H}) .6 .00(\mathrm{~s} .2 \mathrm{H})$. 5.05 (s. 1H). 3.79 (s. $3 \mathrm{H}) .3 .69(\mathrm{~s} .3 \mathrm{H}) .3 .55(\mathrm{~m} .2 \mathrm{H}) .2 .61(\mathrm{t}$ $J=6.5 \mathrm{~Hz} .2 \mathrm{H})$. MS. $m e(\%): 369\left(\mathrm{M}^{-}, 34\right) .322(57) .22 \mathrm{l}$ (60), 174 (100).

9,10-Dimethoxy-5,6-dihydro[1,3]dioxolo[4,5-g]isoquino$[3,2-a]$ isoquinolin-8-one (8-oxoberberine) (4). The mixture of compound 7 (100 $\mathrm{mg} .0 .28 \mathrm{mmol})$. tosyl chloride (115 mg. $0.6 \mathrm{mmol}$ ). and triethy lamine (60 $\mathrm{mg} .0 .6 \mathrm{mmol}$ ) in $\mathrm{CH}_{2} \mathrm{Cl}_{2}$ was stirred at room temperature for ovenight. The reaction mixture was poured into water and extracted with $\mathrm{CH}_{2} \mathrm{Cl}_{2}$. The extract was dried over anhydrous sodium sulfate. After evaporating off the solvent, the residue was purified by column chromatography with $n$-hexane-ethyl acetate $(1: 1)$ to give 8 -oxoberberine 4 as a yellow solid (61 mg. 63\%). mp: $191-193^{\circ} \mathrm{C}$ (lit. ${ }^{15} 191-193^{\circ} \mathrm{C}$ ). IR $\left(\mathrm{cm}^{-1}\right)$ : $1642(\mathrm{C}=\mathrm{O}) .{ }^{\mathrm{j}} \mathrm{H}$ NMR $\left(300 \mathrm{MHz}, \mathrm{CDCl}_{3}\right) \delta: 7.32$ (d. $J=8.7$ $\mathrm{Hz}, 1 \mathrm{H}) .7 .27(\mathrm{~d}, J=8.7 \mathrm{~Hz}, 1 \mathrm{H}), 7.21(\mathrm{~s}, 1 \mathrm{H}), 6.72(\mathrm{~s}, 1 \mathrm{H})$. $6.70(\mathrm{~s} .1 \mathrm{H}), 6.01$ (s. $2 \mathrm{H}), 4.29(\mathrm{t} J=6.2 \mathrm{~Hz}, 2 \mathrm{H}), 4.01$ (s. $3 \mathrm{H}) .3 .95$ (s. $3 \mathrm{H}) .2 .89$ (t. $J=6.2 \mathrm{~Hz} .2 \mathrm{H})$. MS. $m e(\%): 351$ $\left(\mathrm{M}^{+} .100\right), 336(53), 322(44), 308(4 \mathrm{l})$.

7,8-Dimethoxy-3-[6-(2-methoxymethoxyethyl)benzo[1,3]dioxol-5-yl]-2-methyl-2H-isoquinolin-1-one (8). The mixture of compound 6 (310 mg. $0.75 \mathrm{mmol}), \mathrm{K}_{2} \mathrm{CO}_{3}(517 \mathrm{mg}$.
$3.75 \mathrm{mmol}$ ) and methyl iodide $(210 \mathrm{mg} .1 .5 \mathrm{mmol})$ in DMF $\left(6 \mathrm{~mL}\right.$ ) was heated at $100^{\circ} \mathrm{C}$ for $3 \mathrm{~h}$. The reaction mixture was quenched by water and then extracted with ethyl acetate. The combined ethyl acetate extracts were washed with water. brine and dried over anhydrous sodium sulfate. After removing the solvent. the residue was purified by columun chromatography on silica gel with $n$-hexane-ethyl acetate $(1: 1)$ to give the compound 8 as an oil (196 mg. $61 \%$ ). IR $\left(\mathrm{cm}^{-1}\right)$ : $1645(\mathrm{C}=\mathrm{O}) .{ }^{1} \mathrm{H}$ NMR $\left(300 \mathrm{MHz} . \mathrm{CDCl}_{3}\right)$ $\delta .7 .32(\mathrm{~d}, J=8.7 \mathrm{~Hz} .1 \mathrm{H}) .7 .20(\mathrm{~d}, J=8.7 \mathrm{~Hz} .1 \mathrm{H}), 6.89(\mathrm{~s}$, 1H). 6.69 (s. 1H). 6.27 (s. $1 \mathrm{H}) .6 .02$ (m. 2H). 4.50 (s. $2 \mathrm{H}$ ). $4.02(\mathrm{~s} .3 \mathrm{H}) .3 .95$ (s. $3 \mathrm{H}) .3 .61(\mathrm{~m} .2 \mathrm{H}) .3 .25(\mathrm{~s} .3 \mathrm{H}), 3.20(\mathrm{~s}$. 3H). $2.85(\mathrm{~m} .2 \mathrm{H})$. MS. me (\%): $427\left(\mathrm{M}^{+} .100\right) .358(\mathrm{l} 4)$. $221(59), 198(92), 172(80)$

3-[6-(2-Hydroxyethyl)benzo[1,3]dioxol-5-y]]-7,8-dimethoxy-2-methyl-2H-isoquinolin-1-one (9). To the mixture of compound 8 (162 mg. $0.38 \mathrm{mmol}$ ) in THF (15 mL) was added $10 \% \mathrm{HCl}(5 \mathrm{~mL})$ and then the reaction mixture was refluxed for $2 \mathrm{~h}$. It was poured into water and extracted with ethyl acetate. The ethyl acetate extracts were washed with water. brine and dried over anhydrous sodium sulfate. After removing the solvent. the residue was purified by column cluromatography on silica gel with with $n$-hexane-ethyl acetate $(1: 1)$ to give the alcohol 9 as a solid ( $110 \mathrm{mg} .76 \%$ ). mp: $163-165^{\circ} \mathrm{C}$. IR $\left(\mathrm{cm}^{-1}\right): 3450(\mathrm{OH}) .1650(\mathrm{C}=\mathrm{O}) .{ }^{1} \mathrm{H}$ NMR $\left(300 \mathrm{MHz} . \mathrm{CDCl}_{3}\right) \delta .7 .32$ (d. $\left.J=8.7 \mathrm{~Hz} . \mathrm{lH}\right) .7 .20$ (d. $J=8.7 \mathrm{~Hz}, 1 \mathrm{H}) .6 .93$ (s. $1 \mathrm{H}), 6.70(\mathrm{~s} .1 \mathrm{H}) .6 .28(\mathrm{~s} .1 \mathrm{H})$, 6.01 (m. 2H). 4.01 (s. 3H). 3.95 (s. $3 \mathrm{H}) .3 .72$ (m. 2H). 3.24 (s. 3H), 2.79-2.53 (m. $2 \mathrm{H})$. MS, me (\%): $383\left(\mathrm{M}^{+}, 100\right)$. $368(49) .354(19), 206(18)$

1,2-Dimethoxy-12-methy]-12H-[1,3]dioxolo $\left[4^{\prime}, 5^{\prime}: 4,5\right]-$ benzo $[1,2-c]$ phenanthridin-13-one (5) (oxychelerythrine). The reaction mixture of alcohol $9(70 \mathrm{mg}, 0.18 \mathrm{mmol}) . \mathrm{PCC}$ (80 $\mathrm{mg} .0 .37 \mathrm{mmol}$ ) and NaOAc $(25 \mathrm{mg} .0 .3 \mathrm{mmol})$ in $\mathrm{CH}_{2} \mathrm{Cl}_{2}(8 \mathrm{~mL})$ was stirred for $5 \mathrm{~h}$. The reaction mixture was filtered and the filtrate was washed with $\mathrm{CH}_{2} \mathrm{Cl}_{2}$. The combined solvents were evaporated off and the residue was purified by column cluromatography on silica gel with $n$ hexane-ethyl acetate $(1: 1)$ to afford the oxychelerythrine 5 as a white solid (42 mg. 65\%). mp 198-199 ${ }^{\circ} \mathrm{C}$. (lit ${ }^{23} 197-$ $\left.198^{\circ} \mathrm{C}\right)$. IR $(\mathrm{KBr})\left(\mathrm{cm}^{-1}\right)$ : $1645(\mathrm{C}=\mathrm{O}) .{ }^{\mathrm{j}} \mathrm{H}$ NMR $(300 \mathrm{MHz}$, $\left.\mathrm{CDCl}_{3}\right) \delta .8 .00(\mathrm{~d} . J=9.0 \mathrm{~Hz} . \mathrm{lH}) .7 .98(\mathrm{~d} . J=9.0 \mathrm{~Hz}, \mathrm{lH})$ 7.58 (d. $J=9.0 \mathrm{~Hz} . \mathrm{lH}), 7.38$ (d, $J=9.0 \mathrm{~Hz}, 1 \mathrm{H}), 7.52$ (s. 1H). $7.16(\mathrm{~s} .1 \mathrm{H}) .6 .10$ (s. 2H). 4.08 (s. 3H). 3.98 (s. $3 \mathrm{H})$. 3.90 (s. 3H). MS. me (\%): 363 (M. 35). 348 (15). 334 (14). 305 (18). 190 (20). 57 (100). Anal. Calc. for $\mathrm{C}_{21} \mathrm{H}_{17} \mathrm{NO}_{5}: \mathrm{C}$, 69.4l: H. 4.72: N, 3.85. Found: C, 69.63; H. 4.69: N, 3.87.

Acknowledgement. This work was supported by Korea Research Foundation Grant (KRF-2003-041-E00336).

\section{References}

1. Mackay. S. P.: Meth-Cohn. O: Waich. R. D. In Adwances in Heterocychic Chentistry: Academic Press: Orlando. 1997: Vol. 67.

2. Simanek. V. The Alkaloids: Academic Press: Orlando. 1985; Vol. 26

3. Lee. Y. S.: Kim, W. S.: Kim, K. H.; Yoon. M. J.; Cho, H. J.: Shen, 
Y:: Ye. J. M.: Lee. C. H:: Oh. W. K.: Kim. C. T.: Hohnen-Behrens. C.: Gosby. A.: Kraegen. E. W.: James. D. E.: Kim. J. B. Diabetes 2006. 55.2256

4. Lin. C. C.: Kao. S. T.: Chen. G. W.: Chung. J. G. Anticanter Res. $\mathbf{2 0 0 5}, 25,4149$

5. Letasiova. S.: Jantova. S.: Cipak, L.: Muckova, M. Cancer Lett. $2006,239,254$

6. Yu. H. H.: Kim. K. J.: Cha. J. D.: Kim. H. K.: Lee. Y. E.: Choi. N. Y.: You. Y. O.J. Afed Food 2005, 8. 454

7. Hwang. J. M.: Kuo. H. C.: Tseng. T. H.: Liu. J. Y: Chu. C. Y. Arch. Toxicol. $2006,80.62$.

8. Cho, B. J.: Im, E. K: Kwon, I. H.: Lee, K. H: Shin. H. J.: Oh, J.: Kang. S. M: Chung. J. H.: Jang. Y. Hol. Cells 2005. 20.429.

9. Kong. W. Wei. J.: Abidi. P.: Lin. M.: Inaba. S.: Li. C.: Wang. Y.: Wang. Z.: Si. S.: Pan. H.: Wang. S.: Wu. J.: Wang. Y.: Li. Z.: Liu. J. Jiang. J. D. Not. led 2004. 10. 1344.

10. Kemenr-Beke, A.: Aradi J.: Damjanotich J.: Beck Z.: Facsko. A.: Berta. A.: Bodnar A. Cancer Lett. 2006. 237.67.

11. Hoffmann. T. K.: Leenen. K.: Hafner, D.: Balz, V.: Gerharz, C. D.: Grund. A.: Ballo. H.: Hauser. U.: Bier. H. Antichncer Drugs 2002. 13.93 .
12. Lou. H.: Ookhtens, M.; Stolz, A.; Kaplowitz. N. Am. I. Physiol. Gastrointest Liver Phwsiol. 2003. 285. G1335.

13. Ishikawa. T.: Ishii. H. Heterocycles 1999. 50.627.

14. Clement. B.: Weide. M.: Wolschendorf. U.: Kock. I. Angew Chem. Int. Ed. 2005. H4.635.

15. Le. T. N.; Gang, S. G.: Cho. W. J. J. Org Chem 2004. 69. 2768.

16. Le. T. N.: Gang. S. G: Cho. W. J. Tetrohedron Lett 2004. +5. 2763.

17. Takao. N.: Kamigauchi. M.: Okada. M. Helv Chim Acta 1983. 66.473

18. Cho. W. J; Kim. E. K.: Park, I. Y.: Jeong, E. Y; Kim. T. S.; Le. T N.: Kim. D. D.: Lee. E. S. Bioorg. Med. Chem 2002. 10, 2953.

19. Cho. W. T.: Min. S. Y.: Le. T. N.: Kim. T. S. Bioorg. Med Chent Lett. 2003. 13. 4451 .

20. Cho. W. J.: Park. M. J.: Chung. B. H.: Lee. C. O. Bioorg Med. Chem. Lett. 1998, \&.41

21. Poindexter. G. S. J. Org. Chem. 1982, $47,3787$.

22. Le. T. N.: Cho. W. J. Chem. Pham. Bull 2005, 53,118

23. Hanaoka. M.: Motonishi. T.: Mukai. C. J. Chem. Soc. Perkin Trans. $]$ 1986. 2253. 